\title{
International Brain Research Organization-Asia Pacific Regional Committee Neuroscience School - Colombo, Sri Lanka, 2015
}

\author{
Ranil de Silva \\ Interdisciplinary Center for Innovation in Biotechnology and Neuroscience, University of Sri Jayewardenepura, \\ Gangodawila, Nugegoda, Sri Lanka
}

An international workshop on the theme 'From Bench to Bedside: Translational Neuroscience Research in Healthy Brain Aging and Neurological Disorders' was held at the University of Sri Jayewardenepura (USJP) from December 14-20, 2015, with the participation of Honorable Minister of Nutrition and Indigenous Medicine, Dr. Rajitha Senaratne and Honorable Minister of Primary Industries, Daya Gamage (fig. 1, 2). About 32 faculty of internationally acclaimed academic repute and clinicians representing renowned institutions of higher learning participated from Australia (3), China (11), India (8) (Centre for DNA Fingerprinting and Diagnostics-2, Centre for Neuroscience, Indian Institute of Science-1, CSIR-Institute of Genomics and Integrative Biology-1, Jagadguru Sri Shivarathreeswara University-1, National Institute of Mental Health and Neuro Sciences-1, Panjab University-1, Post Graduate Institute of Medical Education and Research-1), Japan (1), Malaysia (2), Netherlands (1), Singapore (1), Thailand (1), UK (1), USA (3) and participants for the workshop included 11 international faculty from Asia Pacific Region (China (1), India (4), Iran (3), Nepal (1), Pakistan (1), Thailand (1)) while 35 participants were there from Sri Lanka. The aim of the meeting was to support a transition of the current research culture in the region from descriptive to innovative multidisciplinary research by providing exposure to cutting edge technology. This workshop was a joint venture with

\section{KARGER}

(c) 2016 S. Karger AG, Basel

0972-7531/16/0232-0122\$39.50/0

E-Mail karger@karger.com

www.karger.com/aon the International Brain Research Organization (IBRO) through the Asia Pacific Regional Committee (APRC). Participants of the workshop included graduates, postgraduates, scientists, academics and industrialists (fig. 3). Lectures covered 5 main areas (molecular diagnostics of neurodegenerative, neuromuscular diseases and stroke, neuropathology, proteomics, cell culture techniques, mind relaxation and natural products in healthy brain aging) and hands-on training in proteomics, nanotechnology, cell culture techniques and molecular genetics including PCR, RT-PCR, TP-PCR, MLPA, mass spectrometry, brain cancer and ayurgenomics related information. Five symposia were organized with over 100 participants: (a) symposium on the use of natural products unique to Sri Lanka to foster healthy brain aging to bridge industry and academia in private-public partnerships through medicinal plants unique to Sri Lanka, (b) symposium on Parkinson's disease and movement disorders by the International Parkinson's and Movement Disorders Society to bridge the gap between neuroscientists and clinicians, (c) symposium by the European Graduate School of Neuroscience (EURON) to facilitate double doctorate opportunities in neuroscience between EURON and USJP, (d) symposium by the Chinese Neuroscience Society, being the first joint symposium between China and Sri Lanka and (e) symposium on mindfulness and mind relaxation in healthy brain aging. 


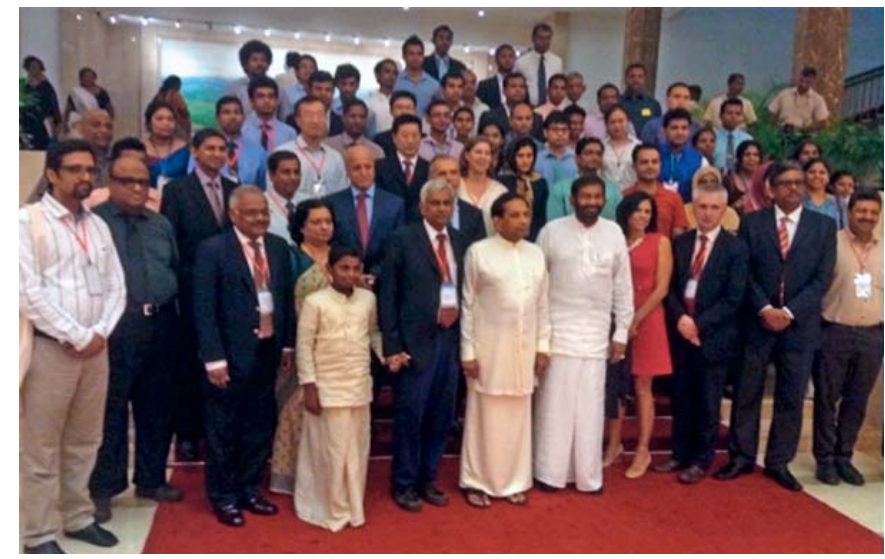

Fig. 1. Honorable Dr. Rajitha Senarathne, Minister of Nutrition and Indigenous Medicine and Honorable Minister Daya Gamage, Minister of Primary Industries and part of attendees, at the symposium on the natural products.

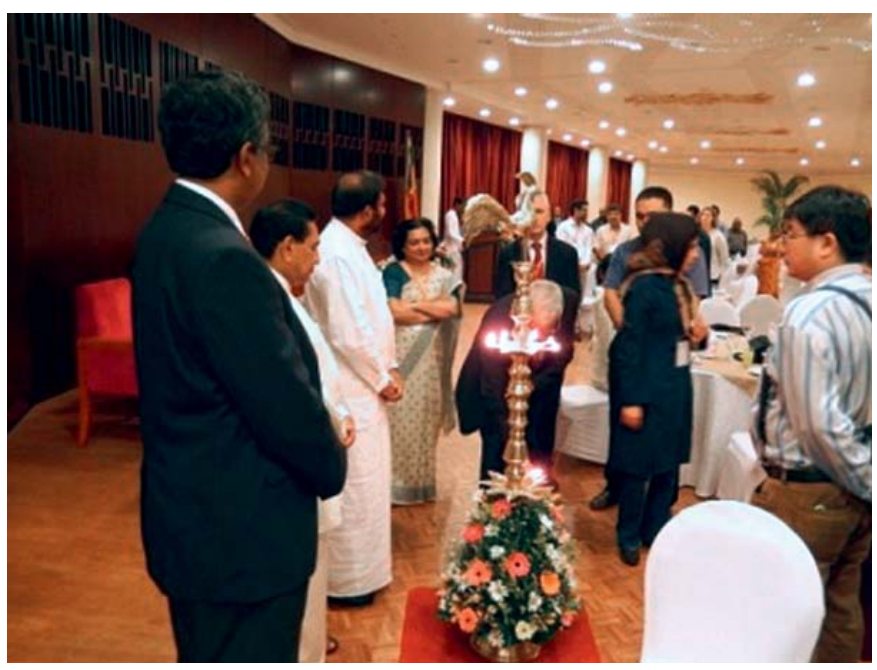

Fig. 2. Lightening of traditional oil lamp by Honerable Ministers and Faculty from India at the symposium on the natural products.

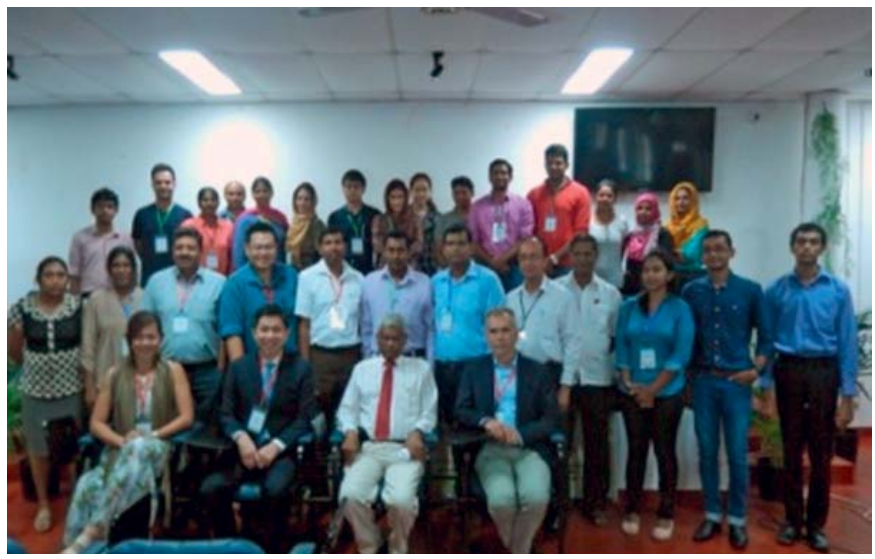

Fig. 3. Part of international faculty and participants at the workshop.

\section{Outcome}

During the workshop, Honorable Ministers, Faculty members from India and Prof. Ranil de Silva, Local Organizer IBRO-APRC Neuroscience School, Colombo, and the industry had discussion for the scientific collaborations between India and Sri Lanka in (1) brain bank: brain samples from India and Sri Lanka, screened for aging pathologies for neurodegenerative disease (http:// benthamscience.com/journals/current-alzheimerresearch/volume/13/issue/3/page/268/), (2) bio-repository of DNA/gene bank and sociodemographic and clinical data of over 2,000 patients and (3) native medicinal plants will be further strengthen by the proposed Economic and Technology Cooperation Agreement (http:// www.sjp.ac.lk/wcup/IBRO/index.php/ and http://www. sjp.ac.lk/wcup/IBRO/symposium.php). 